\title{
MENINGKATAN KEMAMPUAN PEMECAHAN MASALAH MATEMATIKA SISWA MELALUI PENERAPAN MODEL PEMBELAJARAN NHT BERBANTUAN ALAT PERAGA
}

\author{
W. R. Fitria, I P. W. Ariawan, I G. N. Pujawan \\ Program Studi S1 Pendidikan Matematika, Jurusan Matematika, \\ Universitas Pendidikan Ganesha \\ Singaraja, Indonesia \\ e-mail: rizkidoublek@yahoo.com, putu wisna ariawan@yahoo.com,ngrpujawan@yahoo.com
}

\begin{abstract}
Abstrak
Penelitian ini bertujuan untuk mendeskripsikan peningkatan kemampuan pemecahan masalah matematika siswa dan mengetahui tanggapan siswa terhadap Penerapan Model Pembelajaran Numbered Heads Together Berbantuan Alat Peraga. Jenis penelitian ini adalah Penelitian Tindakan Kelas yang dilaksanakan dalam tiga siklus dengan subjek siswa Kelas IX B SMP Maulana Pegayaman semester ganjil Tahun Ajaran 2018/2019 sebanyak 24 siswa. Data kemampuan pemecahan masalah matematika siswa diperoleh melalui tes kemampuan pemecahan masalah matematika dan data tanggapan siswa diperoleh melalui angket. Tes kemampuan pemecahan masalah matematika pada Siklus I menghasilkan rata-rata skor sebesar 46,9, Siklus II sebesar 57,9, dan Siklus III sebesar 77,0. Ketuntasan belajar klasikal siswa pada Siklus I sebesar $12,5 \%$, Siklus II sebesar $50 \%$, dan Siklus III sebesar $79,2 \%$. Peningkatan kemampuan pemecahan masalah matematika terjadi karena pembelajaran memberi kesempatan semua siswa untuk berdiskusi secara berkelompok dan mengemukakan pendapat serta ide-idenya untuk menyelesaikan permasalahan yang diberikan, pembelajaran yang dipadukan dengan penggunaan alat peraga dapat membantu siswa memperagakan suatu konsep secara nyata dalam kegiatan pembelajaran, dan adanya upaya perbaikan terhadap kendala yang ditemukan dalam kegiatan pembelajaran. Selain itu, tanggapan siswa terhadap penerapan Model Pembelajaran Numbered Heads Together berbantuan Alat Peraga berada pada kategori positif dengan rata-rata skor tanggapan siswa sebesar 44,9.
\end{abstract}

Kata kunci: Alat Peraga, Numbered Heads Together, Pemecahan masalah matematika.

\begin{abstract}
The purpose of this study was to describe the improvement of students' mathematical problem solving ability and find out the students' responses to the Application of Numbered Heads Together Learning Model Assisted by teaching aids. The type of this study was Classroom Action Research conducted in three cycles in which the subjects were the 9th B grade students of SMP Maulana Pegayaman in the odd semester academic year 2018/2019 which amounts of students were 24. The obtained Data on students' mathematical problem solving ability were the test of mathematical problem solving abilities and the obtained data on students' response were the questionnaires. The test of mathematical problem solving ability in the first cycle resulted 46.9 as the average score, in the second cycle was 57.9 , and in the third cycle was 77.0. Classical learning completeness of students in the first cycle was $12.5 \%$, in the second cycle was $50 \%$, and in the third was $79.2 \%$. The improvement of mathematical problem solving abilities occur because the learning gives all students the opportunity to discuss in groups and express their opinions and ideas to solve problems given, the learning which is combined with the use of teaching aids can help students demonstrate a concept in real learning activities, and there is an effort to reduce the obstacles found in learning activities. In addition, students' responses to the application of Numbered Heads Together Learning Model assisted by teaching aids are in the positive category with 44,9 as the average score on students' responses.
\end{abstract}

Keywords: Matematical Problem Solving, Number Heads Together Learning Model, Teaching Aids 


\section{PENDAHULUAN}

Kemampuan pemecahan masalah salah satu kemampuan yang harus dimiliki peserta didik dalam mempelajari matematika. Istilah pemecahan masalah mengacu pada tugas matematika yang memiliki potensi dalam memberikan tantangan intelektual sebagai upaya dalam meningkatkan pemahaman matematika (NCTM, 2010). OECD $(2014,28)$ juga menyatakan bahwa "Problem solving competence is an essential component of the skills required to perform interpersonal and non-routine analytic task successfully". Pendapat tersebut bararti bahwa kemampuan pemecahan masalah merupakan komponen penting dari keterampilan yang dibutuhkan siswa dalam mengelola tim dan mengolah data atau informasi dari permasalahan non-rutin yang didapatkannya dengan sukses.

Berdasarkan pengamatan yang dilakukan peneliti di Kelas IX B SMP Maulana Pegayaman ditemukan sebuah masalah. Hasil wawancara yang penulis lakukan terhadap guru mata pelajaran dan dan observasi Kelas IX B SMP Maulana Pegayaman diperoleh bahwa:

1. Siswa kurang aktif dalam kegiatan pembelajaran.

2. Siswa kesulitan dalam memahami permasalahan yang diberikan.

3. Siswa menyatakan bahwa terdapat banyak rumus atau konsep dalam pembelajaran.

4. Siswa mengalami kesulitan dalam memahami contoh-contoh yang diberikan atau yang terdapat di buku yang berkaitan dengan permasalahan yang serupa.

5. Sebagian besar siswa hanya menerima begitu saja hasil diskusi penyelesaian masalah tanpa melakukan konfirmasi kembali.

Berdasarkan hasil wawancara dan observasi tersebut, penulis mendiagnosa bahwa siswa kelas IX B SMP Maulana Pegayaman memiliki kemampuan pemecahan masalah matematika yang kurang. Namun, untuk lebih memastikannya, peneliti juga melakukan pengukuran terhadap kemampuan pemecahan masalah siswa Kelas IX B SMP Maulana Pegayaman. Pengukuran dilakukan dengan melakukan tes tertulis yang terdiri dari lima soal uraian. Berdasarkan hasil pengukuran, diperoleh bahwa rata-rata nilai kemampuan pemecahan masalah siswa masih berada di bawah Kriteria Ketuntasan Minimum yang ditetapkan oleh sekolah, sehingga dapat disimpulkan bahwa memang benar kemampuan pemecahan masalah matematika ternilai kurang.

Salah satu alternatif yang dapat diterapkan sebagai upaya untuk meningkatkan kemampuan pemecahan masalah matematika siswa Kelas IX B SMP Maulana Pegayaman adalah dengan menerapkan model pembelajaran yang sesuai dengan indikator yang ingin dicapai dan kondisi siswa. Salah satu model pembelajaran yang mendukung dan dapat diterapkan untuk mengatasi hal tersebut adalah model pembelajaran numbered heads together. Dengan menerapkan model pembelajaran numbered heads together, kemampuan pemecahan masalah matematika barada pada kualifikasi baik (Noor, 2014).

Pembelajaran kooperatif tipe numbered heads together (NHT) menurut Yudiastuti (2014) merupakan model pembelajaran yang menekankan pada stuktur khusus yang dirancang untuk mempengaruhi pola interaksi antar siswa dan memiliki tujuan untuk meningkatkan penguasaan akademik siswa. Numbered heads together adalah model yang memberikan kesempatan kepada siswa untuk saling memberikan ide-ide dan pertimbangan jawaban yang paling tepat. Menurut Noor (2014) langkah-langkah dari model pembelajaran ini yaitu 1) Penomoran, guru membagi siswa kedalam beberapa kelompok yang beranggotakan 3-5 siswa kemudian guru memberikan nomor kepada setiap anggota kelompok. 2) Mengajukan pertanyaan, guru mengajukan beberapa pertanyaan yang bervariasi kepada siswa. 3) Berpikir bersama, siswa diberikan kesempatan untuk berdiskusi tentang pertanyaan yang telah diberikan oleh guru. 4) Menjawab, siswa akan dipanggil dengan nomor tertentu kemudian 
siswa yang nomornya sesuai akan menjawab pertanyaan. Kelebihankelebihan model pembelajaran numbered heads together adalah semua siswa menjadi siap, siswa melakukan diskusi dengan sungguh-sungguh, siswa yang memiliki kemampuan lebih bisa mengajari atau membantu siswa yang mempunyai kemampuan kurang, dan tidak ada siswa yang mendominasi dalam kelompok. Adapun kekurangannya yaitu kemungkinan terjadi penganggilan kembali siswa yang sama oleh guru dan tidak semua siswa dipanggil oleh guru (Darmasanti, 2015).

Model pembelajaran numbered heads together lebih mengutamakan keterlibatan siswa secara optimal dalam kelompoknya. Siswa dituntut untuk bereksperimen, berdiskusi, menyimpulkan, membuat laporan dan presentasi, yang semuanya harus dialami bersama oleh anggota dalam kelompoknya, maka dari itu sangat cocok apabila model ini diterapkan dengan berbantual alat peraga. Maksud dan tujuan penggunaan alat peraga adalah memberikan variasi dalam cara guru mengajar dan mewujudkan, serta lebih mengarahkan untuk mencapai tujuan pembelajaran yang efektif. Menurut Hamdani (2012) alat peraga merupakan alat bantu yang bisa digunakan oleh guru dalam proses pembelajaran dengan tujuan membantu guru agar proses belajar mengajar menjadi lebih efektif dan efisien. Alat peraga adalah alat (benda) yang digunakan untuk memperagakan fakta, konsep, prinsip atau prosedur tertentu agar tampak lebih nyata/konkrit. Alat peraga berfungsi untuk menyampaikan pesan pembelajaran. Siswa belajar melalui hal konkrit dan autentik agar siswa semakin menguasai konsep pemecahan masalah.

Terdapat beberapa penelitian yang menunjukkan bahwa penerapan model pembelajaran, yaitu penelitian oleh Gusti Ayu Kd Yudiastuti (2014) yang menghasilkan bahwa terdapat perbedaan yang signifikan hasil belajar Matematika siswa yang dibelajarkan melalui penerapan model pembelajaran Tipe Numbered Heads Together berbantuan Benda Konkret dengan siswa yang dibelajarkan melalui pembelajaran secara konvensional pada siswa Kelas V SD Gugus I Kuta Utara Tahun Pelajaran 2013/2014. Hal ini disebabkan karena siswa yang dibelajarkan melalui penerapan model pembelajaran Tipe Numbered Heads Together berbantuan Benda Konkret dalam pembelajarannya dibentuk kelompok-kelompok siswa untuk memecahkan masalah yang dekat dengan dengan lingkungan siswa sesuai dengan materi yang dipelajari. Penelitian lainnya adalah penelitian oleh Aisjah Juliani Noor pada tahun 2014 yang menghasilkan bahwa kemampuan pemecahan masalah matematika siswa dengan menggunakan model pembelajaran kooperatif tipe NHT berada pada kualifikasi baik dan kemampuan pemecahan masalah matematika siswa Kelas VIII SMP yang menggunakan model pembelajaran konvensional berada pada kualifikasi cukup, serta terdapat perbedaan yang signifikan antara kemampuan pemecahan masalah matematika siswa yang menggunakan model pembelajaran kooperatif tipe NHT dengan siswa menggunakan model pembelajaran konvensional.

Adapun tujuan dari penelitian ini yaitu: (1) Mengetahui bagaimana penerapan model pembelajaran numbered heads together berbantuan alat peraga dalam meningkatkan kemampuan pemecahan masalah matematika siswa kelas IX B SMP Maulana Pegayaman, dan (2) Mengetahui tanggapan siswa Kelas IX B SMP Maulana Pegayaman terhadap pembelajaran matematika menggunakan model pembelajaran numbered heads together berbantuan alat peraga.

\section{METODE}

Penelitian ini dilaksanakan di SMP Maulana Pegayaman dengan jenis penelitian yaitu penelitian tindakan kelas (classroom action research) yang secara umum bertujuan untuk meningkatkan serta memperbaiki kualitas dan proses pembelajaran di kelas. Subjeknya adalah siswa Kelas IX B SMP Maulana Pegayaman pada semester ganjil Tahun Ajaran 2018/ 2019. 
Penelitian ini dilaksanakan dalam 3 siklus yang terdiri dari 4 tahapan, yaitu: perencanaan tindakan, pelaksanaan tindakan, observasi/evaluasi, dan refleksi. Pada setiap siklus dilaksanakan 4 kali pertemuan dengan rincian 3 pertemuan untuk membahas materi pelajaran dan satu kali pertemuan untuk melaksanakan tes sebagai bahan evaluasi.

Data yang dikumpulkan dalam penelitian ini berupa data pemecahan masalah matematika siswa melalui pemberian tes setiap akhir siklusnya. Tes disusun dalam bentuk tes uraian yang terdiri dari 3-4 butir soal. Sedangkan, data tanggapan siswa terhadap model pembelajaran numbered heads together berbantuan alat peraga dikumpulkan menggunakan angket tanggapan yang terdiri dari 15 item yang diberikan pada akhir siklus III.

Data mengenai pemecahan masalah matematika siswa dianalisis berdasarkan rata-rata skor yang telah ditetapkan yaitu minimal 74 sesuai dengan Kriteria Ketuntasan Minimal (KKM) mata pelajaran matematika di Kelas IX B SMP Maulana Pegayaman, sehingga kriteria ketuntasan pemecahan masalah matematika siswa disajikan pada Tabel 1.

Tabel 1. Kriteria Ketuntasan Pemecahan Masalah Matematika Siswa

\begin{tabular}{ccc}
\hline No. & $\begin{array}{c}\text { Rata-rata Nilai } \\
\text { Pemahaman } \\
\text { Konsep Siswa }\end{array}$ & Kategori \\
\hline 1. & $74 \leq \bar{X} \leq 100$ & Tuntas \\
2. & $0 \leq \bar{X}<75$ & Tidak Tuntas \\
\hline
\end{tabular}

Dengan diperolehnya rata-rata nilai pemecahan masalah matematika untuk setiap siklus, maka dapat ditentukan kemampuan pemecahan masalah matematika siswa dari siklus I ke siklus II dan dari siklus II ke siklus III
Sedangkan data tanggapan siswa terhadap model pembelajaran numbered heads together berbantuan alat peraga dianalisis secara deskriptif, yakni dengan menghitung rata-rata skor tanggapan siswa dengan kriteria penggolongan yang disajikan pada Tabel 2.

Tabel 2. Kriteria Penggolongan Tanggapan Siswa yang telah dimodifikasi

\begin{tabular}{cc}
\hline Rentangan Skor & Kriteria \\
\hline$\overline{\boldsymbol{T}} \geq \mathbf{4 8}$ & Sangat Positif \\
$\mathbf{3 6} \leq \overline{\boldsymbol{T}}<\mathbf{4 8}$ & Positif \\
$\mathbf{2 4} \leq \overline{\boldsymbol{T}}<\mathbf{3 6}$ & Ragu-ragu \\
$\mathbf{1 2} \leq \overline{\boldsymbol{T}}<\mathbf{2 4}$ & Negatif \\
$\overline{\boldsymbol{T}}<\mathbf{1 2}$ & Sangat Negatif \\
\hline
\end{tabular}

\begin{abstract}
Dari analisis data tersebut, penelitian ini menetapkan kriteria keberhasilan yaitu: (1) kemampuan pemecahan masalah matematika siswa meningkat dari siklus ke siklus dengan ratarata skor pemecahan masalah matematika siswa mencapai nilai KKM $\geq 74$ serta secara klasikal $70 \%$ siswa mencapai kriteria tuntas, dan (2) ditinjau dari rata-rata
\end{abstract}

skor tanggapan siswa minimal dalam kategori positif. 
HASIL DAN PEMBAHASAN

A. HASIL

\section{Hasil Penelitian pada Siklus I}

Pada akhir Siklus I, siswa diberikan tes kemampuan pemecahan masalah matematika yang terdiri dari empat soal uraian dengan waktu pengerjaan selama 2 $\times 40$ menit. Berdasarkan hasil analisis data yang dilakukan, diperoleh rata-rata nilai kemampuan pemecahan masalah matematika siswa Kelas IX B SMP Maulana Pegayaman adalah 46,9 dan ketuntasan belajar secara klasikal sebesar $12,5 \%$. Meskipun data rata-rata nilai kemampuan pemecahan masalah matematika siswa serta ketuntasan belajar secara klasikal masih belum mencapai indikator keberhasilan, namun hasil dari tes siklus I ini menunjukan bahwa terdapat peningkatan rata-rata nilai dan ketuntasan belajar klasikal dibandingkan dengan tes awal yang dilakukan sebelum diberikan perlakuan. Dengan hasil yang diperoleh pada Siklus I yang belum memenuhi indikator keberhasilan, maka hal ini akan menjadi acuan bahwa perlunya refleksi dan melakukan berbagai perbaikan pada siklus berikutnya.

\section{Hasil Penelitian pada Siklus II}

Pada akhir Siklus II, siswa diberikan tes kemampuan pemecahan masalah matematika yang terdiri dari tiga soal uraian. Berdasarkan hasil analisis data yang dilakukan, diperoleh bahwa rata-rata nilai kemampuan pemecahan masalah matematika siswa sebesar 57,9 dan ketuntasan belajar secara klasikal sebesar $50 \%$. Pada siklus II ini hasil penelitian masih belum memenuhi indikator keberhasilan yang telah ditetapkan. Namun jika dibandingkan dengan hasil pada Siklus I telah terjadi peningkatan baik rata-rata nilai maupun ketuntasan belajar klasikal. Berdasarkan hasil pada Siklus II ini, maka diperlukannya refleksi sebagai upaya perbaikan-perbaikan pada siklus selanjutnya.

\section{Hasil Penelitian pada Siklus III}

Pada akhir Siklus III, siswa diberikan tes kemampuan pemecahan masalah matematika yang terdiri dari tiga soal uraian. Berdasarkan hasil analisis data yang dilakukan, diperoleh bahwa rata-rata nilai kemampuan pemecahan masalah matematika siswa sebesar 77,0 dan ketuntasan belajar secara klasikal sebesar $79,2 \%$. Pada siklus III ini hasil penelitian telah memenuhi indikator keberhasilan yang telah ditetapkan yaitu rata-rata nilai kemampuan pemecahan masalah matematika siswa $\geq 74$ dan ketuntasan belajar klasikal mencapai $\geq 75 \%$. Selain itu, jika dibandingkan dengan Siklus II, hasil pada Siklus III telah mengalami peningkatan baik dilihat dari rata-rata nilai maupun ketuntasan belajar siswa secara klasikal.

Peningkatan rata-rata nilai pemecahan masalah matematika siswa di Kelas IX B SMP Maulana Pegayaman terhadap materi kesebangunan dan unsurunsur tabung, kerucut dan bola, serta persentase ketuntasan mulai dari refleksi awal sampai siklus III pada Gambar 1 .

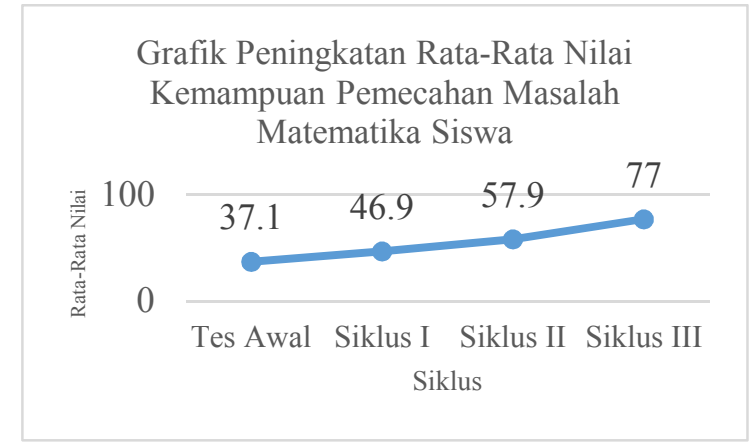

Gambar 1.

Selain itu peningkatan ketuntasan belajar siswa ditunjukkan pada Gambar 2 .

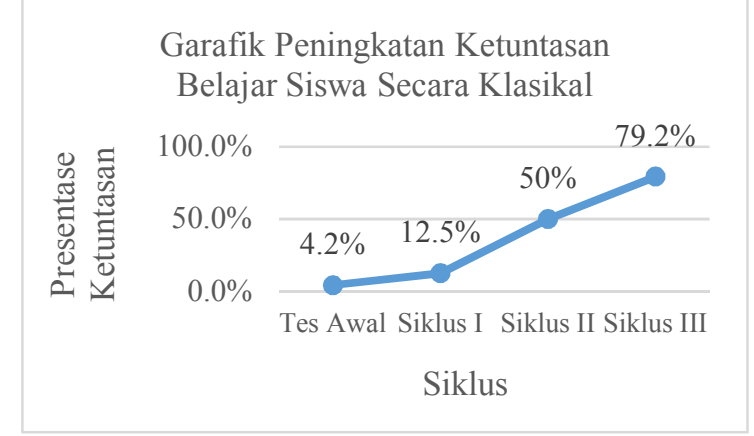

Gambar 2.

Berdasarkan Gambar 2. tampak bahwa pada siklus III presentase ketuntasan belajar siswa adalah $79,2 \%$ 
sehingga telah berada dalam kategori yaitu ketuntasan belajar minimal mencapai $70 \%$

Pada akhir siklus III siswa diberikan angket tanggapan yang bertujuan untuk mengetahui tanggapan siswa terhadap penerapan model pembelajaran numbered heads together berbantuan alat peraga. Adapun sebaran data tanggapan siswa dapat dilihat pada Gambar 3.

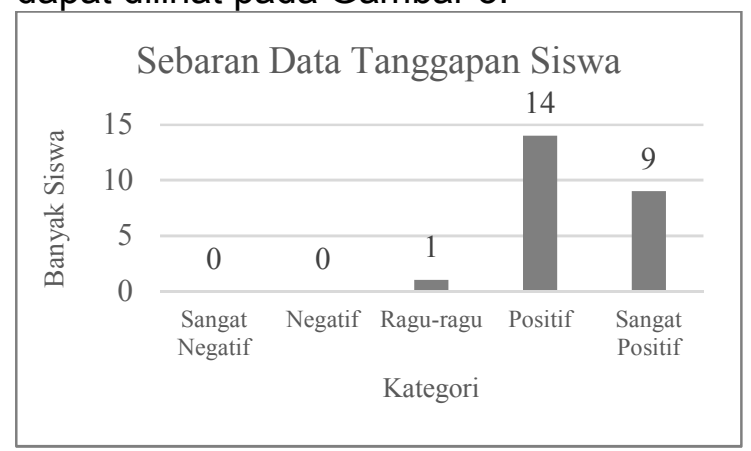

Gambar 3.

Dari Gambar 3. dapat disimpulkan bahwa pembelajaran melalui penerapan model pembelajaran numbered heads together berbantuan alat peraga mendapatkan tanggapan yang masuk dalam kategori "Positif" dari siswa sesuai dengan kriteria penggolongan tanggapan siswa, sehingga tanggapan siswa terhadap penerapan strategi penilaian diri selama proses pembelajaran telah memenuhi kriteria indikator keberhasilan yang ditetapkan.

\section{B. PEMBAHASAN}

Berdasarkan hasil penelitian yang telah dilaksanakan selama 3 (tiga) siklus menunjukkan adanya peningkatan pemecahan masalah matematika siswa Kelas IX B SMP Maulana Pegayaman terhadap penerapan model pembelajaran numbered heads together berbantuan alat peraga. Peningkatan kemampuan pemecahan masalah matematika pada tiap siklusnya ditunjukkan pada Tabel 3 berikut.

Tabel 3. Ringkasan peningkatan kemampuan pemecahan masalah matematika

\begin{tabular}{cccc}
\hline Tahap & $\begin{array}{c}\text { Rata- } \\
\text { Rata } \\
\text { Nilai }\end{array}$ & $\begin{array}{c}\text { Ketun- } \\
\text { tasan } \\
\text { Belajar }\end{array}$ & Keterangan \\
\hline Tes Awal & 37,1 & $4,2 \%$ & $\begin{array}{c}\text { Belum } \\
\text { Tercapai }\end{array}$ \\
\hline
\end{tabular}

\begin{tabular}{cccc}
\hline Siklus I & 46,9 & $12,5 \%$ & $\begin{array}{c}\text { Belum } \\
\text { Tercapai }\end{array}$ \\
\hline Siklus II & 57,9 & $50 \%$ & $\begin{array}{c}\text { Belum } \\
\text { Tercapai }\end{array}$ \\
\hline Siklus III & 77,0 & $79,2 \%$ & Tercapai \\
\hline
\end{tabular}

Adapun hal-hal yang menyebabkan terjadinya peningkatan kemampuan pemecahan masalah matematika siswa adalah sebagai berikut. Pertama, proses pembelajaran dengan model numbered heads together memberi kesempatan semua siswa untuk berdiskusi secara berkelompok dan mengemukakan pendapat serta ide-idenya untuk menyelesaikan permasalahan yang diberikan karena secara garis besar model numbered heads together memiliki kelebihan yaitu lebih mengutamakan keterlibatan semua siswa secara optimal dalam kelompoknya. Siswa dituntut untuk bereksperimen, berdiskusi, menyimpulkan, membuat laporan dan presentasi, yang semuanya harus dialami bersama oleh anggota dalam kelompoknya. Hal ini disebabkan karena dalam menentukan nilai dan penghargaan kelompok, guru menunjuk secara acak salah satu nomor siswa untuk mewakili kelompoknya sehingga semua anggota kelompok mengetahui cara, proses dan hasil atau penyelesaian dari permasalahan-permasalahan yang diberikan. Dengan adanya diskusi yang mengharuskun semua anggota kelompok terlibat maka pemikiran dari setiap anggota kelompok akan mengefektifkan pelaksanaan diskusi. Menurut Ardana (2008), dalam belajar matematika siswa dikatakan dapat memahami konsep dengan baik ketika siswa terlibat secara aktif dalam pembentukan struktur kognitifnya dengan guru bertindak sebagai pengarah agar proses pembentukan struktur kognitif tersebut berjalan dengan lancar. Struktur kognitif siswa terbentuk ketika siswa memikirkan secara mandiri mengenai penyelesaian masalah yang diberikan berdasarkan pengetahuanpengetahuan yang mereka miliki.

Kedua, proses pembelajaran yang dipadukan dengan penggunaan alat peraga, dapat membantu siswa 
memperagakan suatu konsep secara nyata dalam kegiatan pembelajaran karena pada dasarnya siswa belajar melalui sesuatu yang konkret, untuk memahami konsep abstrak siswa memerlukan benda-benda konkret yang dipakai alat peraga sebagai perantara atau visualisasinya. Selain itu, penggunaan alat peraga akan lebih menarik perhatian siswa dan dapat mengembangkan bakat dan minat siswa dengan suasana kelas yang semakin menyenangkan.

Ketiga, beragam perbaikan yang dilakukan pada Siklus II dan III juga berpengaruh besar terhadap peningkatan kemampuan pemecahan masalah siswa. Sebagian besar yang memadai permasalahan dalam proses pembelajaran adalah faktor psikologis siswa sehingga perbaikan yang dilakukan cenderung bersifat psikologis juga, entah berupa pemberian penguatan positif maupun negatif. Mengacu pada refleksi Siklus I dan II, perbaikan yang telah dilakukan guru salah satunya adalah melakukan tanya jawab ketika kegiatan diskusi berlangsung. Menurut Trianto (dalam Rochani, 2014: 14), pemberian pertanyaan-pertanyaan kepada siswa merupakan hal yang sangat berguna untuk memecahkan permasalahan yang dihadapi siswa, membangkitkan respons siswa, mengetahui sejauh mana rasa keingintahuan siswa, memfokuskan perhatian siswa pada sesuatu yang dikehendaki guru, dan menyegarkan kembali pengetahuan siswa. Selain itu, guru juga memberikan beberapa motivasi sebagai pendorong aktifnya siswa dalam mengikuti pembelajaran. Motivasi belajar dapat dijadikan sebagai daya penggerak dalam diri siswa yang menciptakan keinginan siswa untuk belajar, menjamin keberlangsungan kegiatan belajar, dan memberi arah pada kegiatan belajar, sehingga tujuan yang diinginkkan dari subjek belajar dapat tercapai.

Keberhasilan penelitian ini tidak hanya ditinjau dari peningkatan kemampuan pemecahan masalah matematika siswa yang berasal dari hasil tes pada setiap siklus, namun data tanggapan siswa terhadap penerapan
Model Pembelajaran Numbered Heads Together berbantuan Alat Peraga juga merupakan indikator lain yang diperhitungkan. Berdasarkan hasil rekapitulasi data tanggapan siswa, diperoleh bahwa tanggapan siswa berada pada kategori positif. Ini menunjukkan bahwa indikator keberhasilan yang berasal dari tanggapan siswa telah terpenuhi.

Secara umum, hasil yang diperoleh dalam penelitian ini sejalan dengan penelitian yang dilakukan oleh Gusti Ayu Kd Yudiastuti yang menunjukkan bahwa terdapat perbedaan yang signifikan hasil belajar Matematika siswa yang dibelajarkan melalui penerapan model pembelajaran Tipe Numbered Heads Together berbantuan Benda Konkret dengan siswa yang dibelajarkan melalui pembelajaran secara konvensional pada siswa Kelas V SD Gugus I Kuta Utara Tahun Pelajaran 2013/2014. Hal ini disebabkan karena siswa yang dibelajarkan melalui penerapan model pembelajaran Tipe Numbered Heads Together berbantuan Benda Konkret dalam pembelajarannya dibentuk kelompokkelompok siswa untuk memecahkan masalah yang dekat dengan dengan lingkungan siswa sesuai dengan materi yang dipelajari. Hal tersebut juga ditemukan dalam penelitian ini, dengan dibentuknya kelompok-kepmpok siswa secara heterogen untuk memecahkan masalah dan dengan menggunakan alat peraga dalam menyelesaikan permasalahan pada LKS yang diberikan membuat siswa terbantu dalam menyelesaikannya.

Hasil penelitian ini juga sejalan dengan penelitian yang dilakukan oleh I Gusti Ayu Made Supartini yang menunjukkan hasil belajar matematika dan motivasi berprestasi siswa yang mengikuti model pembelajaran kooperatif tipe NHT berbantuan alat peraga sederhana lebih baik daripada siswa yang mengikuti model pembelajaran konvensional. $\mathrm{Hal}$ ini disebabkan karena model pembelajaran kooperatif tipe NHT pada dasarnya merupakan sebuah varian diskusi kelompok dengan ciri khasnya guru menunjuk seorang siswa yang mewakili 
kelomponya, hal ini menjamin keterlibatan semua siswa dalam proses pembelajaran. Hal tersebut juga ditemukan pada penelitian ini yaitu dengan menunjuk atau memanggil salah satu nomor siswa membuat semua kelompok berdiskusi secara bersungguh-sungguh dan semua siswa memahami cara dan proses penyelesaian masalah yang diberikan pada LKS.

\section{KESIMPULAN DAN SARAN}

Berdasarkan hasil penelitian dan pembahasan yang telah dipaparkan sebelumnya, dapat disimpulkan bahwa:

Pertama, penerapan model pembelajaran numbered heads together berbantuan alat peraga dapat meningkatkan kemampuan pemecahan masalah matematika siswa Kelas IX B SMP Maulana Pegayaman hal tersebut ditinjau dari rata-rata nilai kemampuan pemecahan masalah matematika dan ketuntasan belajar siswa yang di setiap siklusnya mengalami peningkatan. Peningkatan kemampuan pemecahan masalah matematika yang dimiliki siswa Kelas IX B SMP Maulana Pegayaman dari Siklus I ke Siklus II sebesar 11 dengan rata-rata 46,9 pada Siklus I menjadi 57,9 pada siklus II. Kemudian dari Siklus II ke Siklus III mengalami peningkatan 19,1 menjadi 77,0 dengan presentase banyaknya siswa yang tuntas bsebesar $79,2 \%$ pada Siklus III serta telah memenuhi indikator kebrhasilan yakni 74 dan mengalami peningkatan dari siklus ke siklus dan banyaknya siswa yang tuntas melebihi $70 \%$. Peningkatan ini dapat terjadi karena berbagai tindakan yang telah dilakukan, yaitu: (1) pembelajaran memberi kesempatan semua siswa untuk berdiskusi secara berkelompok dan mengemukakan pendapat serta ide-idenya untuk menyelesaikan permasalahan yang diberikan, (2) pembelajaran yang dipadukan dengan penggunaan alat peraga dapat membantu siswa memperagakan suatu konsep secara nyata dalam kegiatan pembelajaran karena pada dasarnya siswa belajar melalui sesuatu yang konkret, (3) adanya upaya perbaikan terhadap kendala yang ditemukan dalam kegiatan pembelajaran.
Kedua, tanggapan siswa Kelas IX B SMP Maulana Pegayaman terhadap penerapan model pembelajaran Numbered Heads Together berbantuan Alat Peraga berada pada kategori positif dengan ratarata skor tanggapan sebesar 44,9. Hal ini menunjukkan bahwa penerapan model pembelajaran Numbered Heads Together berbantuan Alat Peraga telah memberikan ketertarikan lebih bagi siswa untuk belajar matematika, memberikan perasaan senang dan nyaman pada siswa, serta memberikan kemudahan-kemudahan bagi siswa dalam memahami materi pembelajaran. Dengan skor tanggapan siswa yang berada pada kategori positif berarti bahwa indikator keberhasilan telah tercapai.

Adapun saran yang dapat disampaikan berdasarkan hasil penelitian yang telah dilakukan adalah sebagai berikut. 1) Sebagai bentuk inovasi dalam pembelajaran matematika, penerapan model pembelajaran Numbered Heads Together berbantuan Alat Peraga dapat dijadikan salah satu pertimbangan bagi para guru dalam mengajar sebagai upaya peningkatan kemampuan pemecahan masalah matematika siswa, 2) Pada penerapan Model Pembelajaran Numbered Heads Together berbantuan Alat Peraga diharapkan para guru dapat memperhatikan setiap unsur yang terkandung dalam model ini, seperti sintaks, prinsip reaksi, sistem sosial, sistem pendukung, serta dampak instruksional dan dampak pengiring agar pelaksanaan pembelajaran dapat berjalan dengan baik, 3) Bagi pembaca yang memiliki minat untuk memperdalam penelitian dengan penerapan Model Pembelajaran Numbered Heads Together berbantuan Alat Peraga diharapkan agar memperhatikan kendalakendala yang dialami selama pelaksanaan penelitian sebagai pertimbangan dalam rangka perbaikan dan penyempurnaan pelaksanaan dan hasil penelitian. Penerapan Model Pembelajaran Numbered Heads Together berbantuan Alat Peraga juga dapat dijadikan sebagai bahan pertimbangan dalam meningkatkan kemampuan matematis lainnya. 
DAFTAR PUSTAKA

Ardana, I M. 2008. Peningkatan Kualitas Belajar Siswa Melalui Pengembangan Pembelajaran Matematika Berorientasi Gaya Kognitif dan Berwawasan Konstruktivis. Jurnal. Singaraja: Lembaga Penelitian Undiksha.

Darmasanti, I A K A. 2015. Pengaruh Model Pembelajaran Kooperatif Tipe Numbered Heads Together Berbantuan Metode Mind Map Terhadap Hasil Belajar Biologi Siswa Kelas X SMA Negeri 1 Seririt [Skripsi]. Singaraja. Universitas Pendidikan Ganesha.

Hamdani, D., dkk. 2012. Pengaruh Model Pembelajaran Generatif Dengan Menggunakan Alat Peraga Terhadap Pemahaman Konsep Cahaya Kelas VIII Di SMP Negeri 7 Kota Bengkulu. Bengkulu. Jurnal Exacta, Vol. X No.1 Juni 2012. Universitas Bengkulu.

NCTM. 2010. Why is Teaching With Problem Solving Important to Student Learning?. NCTM, Inc. Tersedia pada http://www.nctm.org/uploadedFile s/Research and Advocacy/resea rch brief and clips/Research bri ef 14 - Problem Solving.pdf. Diakses tanggal 9 Maret 2018 pukul 15.46 WITA.

Noor, A J., dkk. 2014. Model Pembelajaran Kooperatif Tife Numbered Heads Together (NHT) Pada Pemecahan Masalah Matematika di Kelas VIII SMP. Banjarmasin. Jurnal Pendidikan Matematika, Vol. 2, No.1.

OECD. 2014. PISA2012 Results: Creative Problem Solving
Students' Skill In Tackling Real Life Problems Volume V. Prancis: OECD Publishing.

Rochani, S. 2014. Peningkatan Hasil Belajar Matematika melalui Model Pembelajaran Kontekstual (Contextual Teaching and Learning) Berbantu alat Peraga Manik-Manik pada Siswa Kelas V SD 1 Panjang Tahun Ajaran 2013/ 2014. Tersedia pada http://repository.uksw.edu/ bitstream/123456789/5251/3/T1 262011050_B:AB\%20II.pdf (diakses pada 4 Juni 2018).

Supartini, IGA M., dkk. Pengaruh Model Pembelajaran Kooperatif Tipe NHT Berbantuan Alat Peraga Sederhana Terhadap Motivasi Berprestasi Dan Hasil Belajar Matematika. Singaraja. Universitas Pendidikan Ganesha.

Yidiastuti, G A K., dkk. 2014. Pengaruh Model Pembelajaran Tipe Numbered Heads Together (NHT) Berbantuan Benda Konkret Terhadap Hasil Belajar Matematika Siswa Kelas V Gugus 1 Dalung Kecamatan Kuta Utara. Singaraja. Jurnal Mimbar PGSD Universitas Pendidikan Ganesha, Vol. 2 No. 1 Tahun 2014 